\title{
How to improve graft survival in hair transplantation?
}

\author{
Aleksiy Makharashvili*, Diana Papaskiri, Maka Doghozashvili and Natalia Filipova \\ Scientific and Medical Centre for Hair Restoration, Hairline International, Tbilisi, Georgia
}

\begin{abstract}
Despite the improvements in the methods of hair transplantation, results are not always satisfying. The viability of grafts is one of the most challenging problems in the hair transplantation. This is especially important in case of mega sessions, when the time of ex vivo maintenance of the follicles increases significantly.

The purpose of our study was to evaluate the morphological changes of grafts and to define time frames of follicles' viability at the various stages of hair transplantation. The research of the follicle ultra-structure has been carried out in an electrical microscope JEM-1200 EX-II according to the mainstream methodic.

On the base of presented results, the timing of various stages of hair transplantation may be optimized to increase the survival rate of grafts and improve the effect of hair transplantation.
\end{abstract}

\section{Introduction}

Hair transplantation is the only effective method to restore hair in case of androgenic and cicatricial alopecia. Its popularity has significantly increased in recent years; consequently the number of the specialists of hair transplantation has risen. Over the past 15 years, hair transplantation has transformed from a simple 1-2 hour procedure, in a very difficult, 5-10-hours microsurgical operation, when it is possible to transplant hundreds and sometimes thousands of grafts. It requires the coordinated work of numerous highly qualified staff. Despite the improvements in the methods of hair transplantation, results are not always satisfying.

The viability of grafts is one of the most challenging problems in the hair transplantation. This is especially important in case of mega sessions, when more than 3,000 grafts are transplanted during one surgical intervention, while the time of ex vivo maintenance of the follicles increases significantly.

One of the key factors, affecting the grafts survival is warming and dehydration of grafts. Generally recognized method of graft preservation is cooling them to $+4-5^{\circ} \mathrm{C}$ in saline or Ringer solution.

What happens in follicles during the time of ex vivo maintenance? This is the question to which we would like to answer. For this reason we have carried out an original research.

The purpose of our study was to evaluate the morphological changes of grafts and to define time frames of follicles' viability at the various stages of hair transplantation.

\section{Material and methods}

All the patients included into the study underwent autological hair transplantation by the method of micrografting with use of strip technique. After excision of donor strip, dissecting the grafts was performed with the use of stereoscopic microscopes, the prepared grafts (Figure 1) were collected on a gauze container soaked in saline (25-30 grafts per container) and kept in a fridge at $+4-+5^{\circ} \mathrm{C}$ ) until implantation to recipient zone. During the implantation the container was placed on the back of surgeon's hand. This is the classical scheme of working used by the majority of hair transplantation specialists.

The morphological changes of the grafts (each consisting of 1-3 follicles) were studied placed on the preparatory table after 10-20 minutes, after preparing them with the intervals of $2 \mathrm{~min}$. (30 grafts have been studied). The grafts have been studied in the process, started from the $3^{\text {rd }}$ minute after being placed on the glove with the intervals of 1 minute for 8 minutes ( 30 grafts totally). The grafts placed in the fridge have been studied for 2 to 24 hours.

The tissues were embedded and Epon-812, cut and stained as semithin slices for choice of the region of interest. Then the chosen areas of samples were prepared for TEM following the conventional protocol and studied under transmission electron microscope JEM-1200 EX-II (Japan).

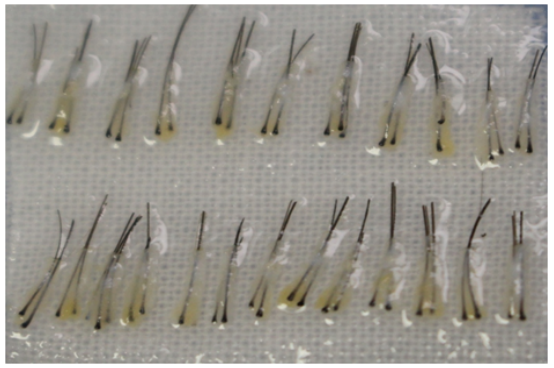

Figure 1. The total image of micrografts.

Correspondence to: Aleksiy Makharashvili, Scientific and Medical Centre for Hair Restoration, Hairline International, Tbilisi, Georgia, E-mail: alex-m70@list.ru

Key words: hair transplantation, graft survival, hair loss treatment, androgenic alopecia, cicatricial alopecia

Received: October 25, 2016; Accepted: November 08, 2016; Published: November 12, 2016 


\section{Results}

It has been shown that in 10 minutes after dissection the cells of germinative zone of follicles were well preserved in the grafts located on the preparatory table at room temperature $\left(22^{\circ} \mathrm{C}\right)$ (Figure 3 ).

The dynamics of the grafts viability, located on the preparatory table, depending on the period of their being on the container has shown that after 12 minutes there were significant changes at the ultrastructural level, and in 20 minutes the irreversible changes were noticed, meaning cellular death (Figure 4). These changes indicated rupture of cell membranes (plasma membranes were not visible), destruction of cytoplasmic organelles, elution of chromatin from nuclei.

The plasma membranes are not visible. The cytoplasmic organelles are destroyed, washed chromatin nuclei. Changes are irreversible cellular death.

The grafts placed on surgeon's glove remained intact during the first 4 minutes (Figure 4).

The dynamics of the study showed that after 5 minutes their viability notably decreased and on the $8^{\text {th }}$ minute the grafts died (Figure 6).

The grafts, which were kept in a fridge at $+4-+5{ }^{\circ} \mathrm{C}$, demonstrated

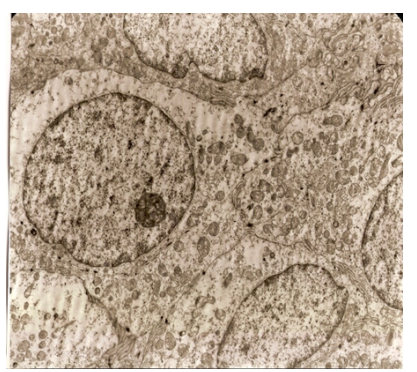

Figure 2. A germinative zone of the follicles right after dissecting the grafts.,,Healthy cells".

Poorly differentiated cells, without the signs of specific differentiation, are well kept with large nuclei. Moderate amounts of organelles. The cells are densely adjacent to each other Plasma membrane form the contacts in the type of desmosomes with digitiform protrusion.

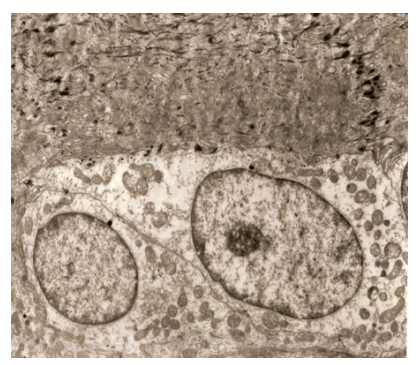

Figure 3. A germinative zone of the follicles $10 \mathrm{~min}$. after dissecting. Well kept cells. The same contacts, as in , healthy" cells.

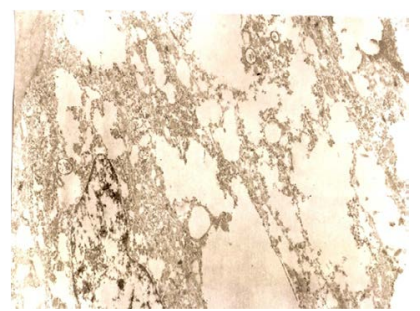

Figure 4. A germinative zone of the follicles $20 \mathrm{~min}$. after dissecting.

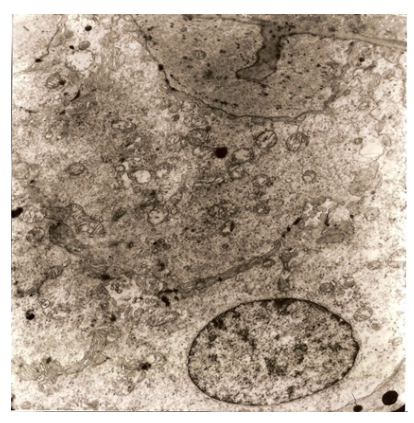

Figure 5. Agerminative zone of the follicles $4 \mathrm{~min}$. after placing on the doctor's glove. The cells are kept. Characterized by the formation of small cavities between them with microvilli.(Viable cells)

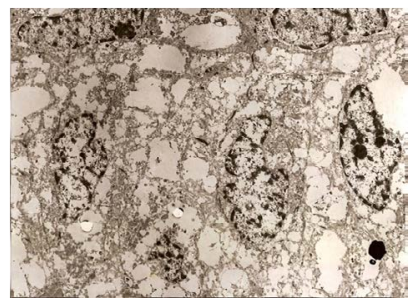

Figure 6. A germinative zone of the follicles $8 \mathrm{~min}$. after placing on the doctor's glove. The plasma membranes are not kept. (rupture of membrane structures). nuclear membrane partially destroyed. Chromatin cores partially washed. Changes are irreversible - cellular death.

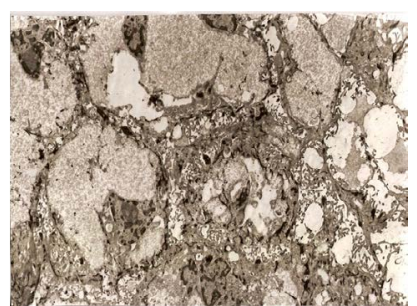

Figure 7. A germinative zone of the follicles 24 hours after placing into the fridge. Irregularly shaped cells, with small number of organelles in the cytoplasm and large structureless bands.Cores of irregular shape with condensed chromatin.Plasma membrane with multiple microvilli. (membrane structures kept). The cells are viable.

Table 1. Viability of grafts depending on the period of their being on the container.

\begin{tabular}{|c|c|c|}
\hline \multirow{2}{*}{$\begin{array}{c}\text { Time } \\
(\mathbf{m i n})\end{array}$} & \multicolumn{2}{|c|}{ Number of grafts } \\
\cline { 2 - 3 } & $\begin{array}{c}\text { Total number of } \\
\text { grafts }\end{array}$ & $\begin{array}{c}\text { Number of viable } \\
\text { grafts }\end{array}$ \\
\hline 10 & 5 & 5 \\
\hline 12 & 5 & 4 \\
\hline 14 & 5 & 2 \\
\hline 16 & 5 & 2 \\
\hline 18 & 5 & 1 \\
\hline 20 & 5 & 0 \\
\hline
\end{tabular}

perfect structural conditions during the first 3-4 hours, while a viability rate at 24 hours was about $71 \%$.

\section{Conclusion}

Performing the electro microscopic study of the structural condition of the grafts has allowed to identify time frames of their survival.

1. Graft spending time on the container during dissecting _ not more than 10 minutes.

2. Graft placing time on the doctor's hand during the 
Table 2. Viability of grafts depending on the period of their being on the doctor's glove.

\begin{tabular}{|c|c|c|}
\hline \multirow{2}{*}{$\begin{array}{c}\text { Time } \\
(\mathbf{m i n})\end{array}$} & \multicolumn{2}{|c|}{ Number of grafts } \\
\hline 3 & 5 & Number of viable grafts \\
\hline 4 & 5 & 5 \\
\hline 5 & 5 & 5 \\
\hline 6 & 5 & 3 \\
\hline 7 & 5 & 1 \\
\hline 8 & 5 & 1 \\
\hline
\end{tabular}

transplantation _ not more than 4 minutes (optimally 2-3 min.)

3. The optimal time of the graft kept in the fridge at $+4-5^{\circ} \mathrm{C}$ is 3-4 hours.

On the base of presented results it can be concluded that we can optimize the duration of different stages of hair transplantation. This will increase the survival rate of grafts and improve the results of treatment.

\section{References}

1. Beehner M (2004) Beehner's study of $\mathrm{Fu}$ vs $1.3 \mathrm{~mm}$ minigrafts after one to three sessions; graft survival, growth, and healing studies. Hair Transplantation (4thetdn) New York: Marcel Dekker Pp: 268.

2. Limmer R (2004) Hair growth studies in follicular units/micrografts. Hair Transplantation, 4th edn. New York: Marcel Dekker Pp. 268.

3. Cole J (2009) Status of individual follicular group harvesting. Hair Transpl Forum Int 19: $20-24$.

4. Seager DJ (1997) Micrograft size and subsequent survival. Dermatol Surg 23: 757-761. [Crossref]

5. Beehner M (2010) Comparison of survival of FU grafts trimmed chubby, medium, and skeletonized. Hair Transpl Forum Int 20: 1-6.

6. Frechet P, Beehner M (2006) A multi-center study of the effect of $100 \%$ transaction on hair graft survival, 14th Annual ISHRS, USA.

7. Beehner UW, Mayer M (2004) Studies comparing hair growth after transaction through the bulge area to produce approximately two equal halves, graft survival, growth, and healing studies. Hair Transplantation, 4th edn. New York, Marcel Dekker.

8. Kim JC, Hwang SJ, Lee JJ, Oh BM, Lee SJ, et al. (2002) The Effects of Dehydration, Preservation Temperature and Time on the Hair Grafts. Ann Dermatol 14: 149-52.

9. Belzer FO, Southard JH (1988) Principles of solid-organ preservation by cold storage. Transplantation 45: 673-676. [Crossref]

10. Raposio E, Cella A, Panarese P, Mantero S, Nordström RE, et al. (1999) Effects of cooling micrografts in hair transplantation surgery. Dermatol Surg 25: 705-707. [Crossref]

11. Adanali G, Senen D, Turegun M, Tuncel A, Erdogan B, et al. (2002) Cryopreservation of hair follicles at 20 degrees C: can it work in staged transplantation. Aesthetic Plastic Surg 26: 465-469. [Crossref]

12. Kurata S, Ezaki T, Takayasu S (1997) Long-term in vitro preservation of human follicles. Hair Transpl Forum Int 7: 23

13. Bernstein RM, Rassman WR (1999) The logic of follicular unit transplantation. Dermatol Clin 17: 277-295, viii. [Crossref]

14. Cooley J (2004) Isehemia-reperfusion injury and graft storage solutions. Hair Transplant Forum 14.

15. Gandelman M, Mota AL, Abrahamsohn PA, De Oliveira SF (2000) Light and electron microscopic analysis of controlled injury to follicular unit grafts. Dermatol Surg 26: 25-30. [Crossref]

16. Jiange Q, Wenzhong L, Guocheng Z, Liangbin Y, Wei S (2005) How long can hair follicle units be preserved at 0 and 4 degrees $C$ for delayed transplant? Dermatol Surg 31:23-26. [Crossref]

17. Krugluger W, Moser K, Moser C, Laciak K, Hugeneck J (2004) Enhancement of in vitro hair shaft elongation in follicles stored in buffers that prevent follicle cell apoptosis. Dermatol Surg 30: 1-5. [Crossref]

18. Limmer B (1994) Elliptical donor stereoscopically assisted micrografting as an approach to further refinement in hair transplantation. J Dermatol Surg Oncol 20: 789793. [Crossref]

19. Seager D (2002) The 'One-Pass Hair Transplant' - A six-year perspective. Hair Transplant Forum 12.

20. Shiell R, Norwood O (1984) Hair transplant surgery. Springfield, IL.

21. Uebel C (2005) A new advance in baldness surgery with the platelet-derived growth factor. Hair Transplant Forum 15: 3.

Copyright: (C)2016 Makharashvili A. This is an open-access article distributed under the terms of the Creative Commons Attribution License, which permits unrestricted use, distribution, and reproduction in any medium, provided the original author and source are credited. 